\title{
地形分類を基礎とした庄内川，矢作川の河成平野の比較研究
}

\author{
春山成子*・大矢 雅 彦*
}

\begin{abstract}
隣り合って流れる庄内川，矢作川の河成平野の地形分類図を作成した．地形要素の組合わせは庄内川は小 型自然堤防十高位デルタ十低位デルタ，矢作川は扇状地的自然堤防十高位扇状地的デルタ+低位扇状地的デ ルタとなっており, 著しい地域差が見られた.

この原因を次のように考えた. (a)矢作川は高度分布, 高度分散量, 起伏量平均值共に大きく, かつ風化 しやすい花崗岩からなるため, 山地崩壊が庄内川より大である. (b) 庄内川は河川縦断勾配が緩でかつ盆地, 峡谷の繰り返しとなっており，下流平野一流下する砂礫量は矢作川より少ない（c)縄文海進時に堆積した 海成層上の河成沖積層の厚さは庄内川平野の方が薄い（d)汇濫原の幅は庄内川平野では上，中流は狭く， 下流は広い.このため，上，中流では河道変遷は少なく，洪水は集中型となるが，下流は変遷が大きく，溢 流型となる. 矢作川は汇濫原の幅の変化は少なく, 洪水は平野上流側はショートカット型, 下流側は湓流型 となっている.
\end{abstract}

\section{I 従来の研究と本研究の目的および方法}

本研究地域である庄内川流域では，松沢・嘉藤 (1954), 桑原 (1968)の濃尾平野の地質, 多田・井関 (1955), 海津 (1979), 井関(1980)の濃尾平野の構造, 地殼変動, 海面変動, 大矢・杉浦 (1979)の水害地形 についての研究がある，一方，矢作川流域では井関 (1961)の歴史地理的考察, 谷津 (1954)の河川絽断面 と河床礫の粒度組成, 森山・小沢(1972), 森山・大 橋 (1980)の沖積層と沖積地の微地形, 森山 (1978), 森山・浅井 (1980)の河床堆積物, 大矢・杉浦 (1977) の水害地形の研究がある. 両河川流域にまたがる上 流山地については木曾 (1963)，(太田ほか，1963)貝 塚ほか(1964)，大矢(1971)などの研究がある.

上記研究は主に平野, 河川, 山地を個別的に扱っ ている. また，一般的に河川研究では水文, 侵食, 堆積などは個別的に扱われ，流域を一単位として扱 って, 総合的に研究された例は少ない.

海外での河川流域研究はリズビー(Rizvi, 1955)の ガンジス, ミシシッピ川下流の地形, 地質, 水系, 河道変遷, トリカール(Tricart, 1961) のセネガルデ ルタの営力, 構成物質, 形成時代の相関関係, フォ

\footnotetext{
* 早稲田大学・教育学部
}

ルカー(Volker, 1964)のイラワジデルタの自然地誌, 大矢 $($ Ohya, 1964)の濁水溪, チャオプラヤ, イラワ ジ，ガンジスなど河川下流平野を中心とした研究な どがある.これらは河川下流域についての地形，地 質, 水文, 気候についての研究はされているが，こ れと上流域との関係，また，地形，地質，水文など の諸要素の総合的関係を論じてはいない.

諸外国で有機的, 総合的研究の発達しない理由は 大陸河川の広大さ，国際河川としての調査の制約， 発展途上国, 東欧圈諸国における地形図, 空中写真 の利用上の制約などがあげられる.

そこで筆者らは日本の河川で, 特に重要な意味を もつ河川下流平野の地形分類を行ない，その特色を 把握し，次いでこれをもたらした要因を全流域から 総合的，総観的に見ることを目ざした．河川の一般 的特性を導き出すには単独の河川研究より, 複数河 川を比較研究する方が優れていると考え，今回は隣 り合って流れる庄内川, 矢作川流域を調查対象とし た.

これからの河川研究は広い分野にまたがって行な われるべきである，そこで，本研究は大矢(1982)の 提唱した「河川流域の総観的研究を踏まえた有機的 構造をむつ自然地誌」と規定される河川地理学の発 
展に寄与すると考える.

本研究は 1)両河川下流平野の地形を分類し, 地 形要素およびその組合わせの特色を明確にする，2) この特色をもたらした原因を(a) 砂礫供給源として の山地地形, 地質, (b) 砂砂運搬路としての河川の
河床綖断型， (c ) 砂礫流動に大きな影響を与える盆 地, 峡谷の分布, (d) 河床堆積物の粒度組成, (e ) 縄文海進堆積物を被覆する河成沖積層の前地形, （f ) 本支川の堆積関係, 洪水型などに求めるという 方法をとった.

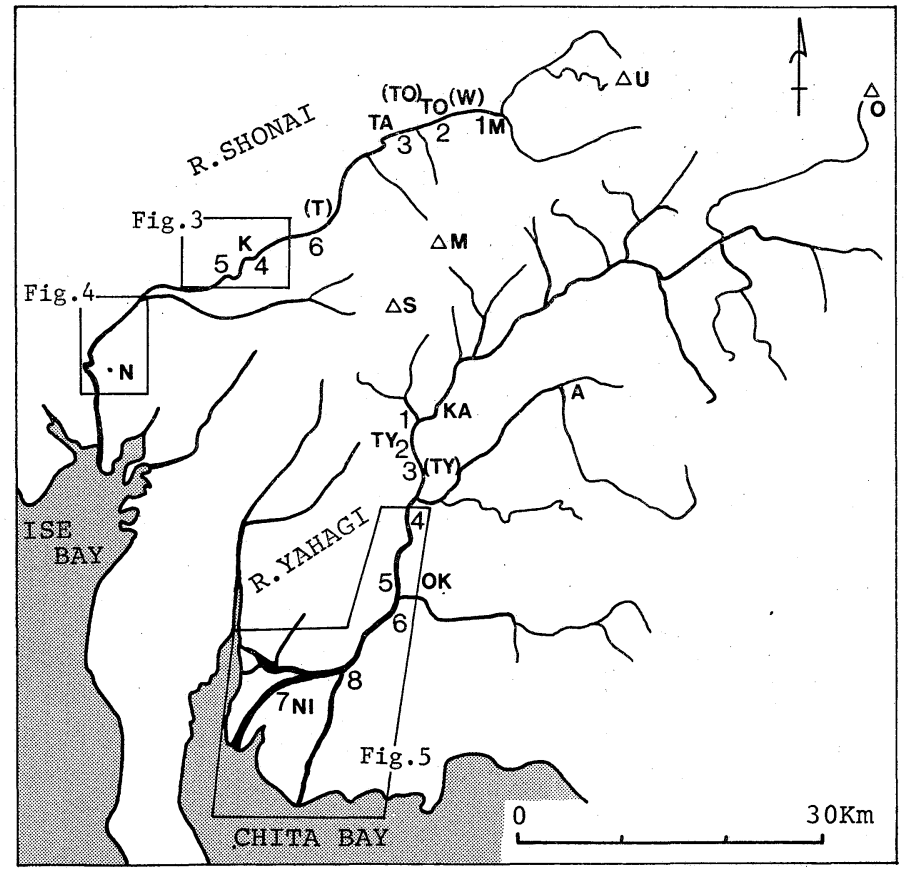

第 1 図庄内川，矢作川流域概観図(粒度分析位置図を含む)

庄内川 $\mathrm{U}$ : 夕立山 $\mathrm{M}$ : 瑞浪 $(\mathrm{W})$ : 和合峡谷 $\mathrm{TO}$ : 土岐盆地 (TO) : 土岐峡谷 $\mathrm{TA}$ : 多治見盆地 $(\mathrm{T})$ : 玉野峡谷 $\mathrm{K}$ : 高蔵寺 $\mathrm{N}$ : 名古屋

矢作川 $\mathrm{O}:$ 戒川入.山 $\mathrm{M}:$ 三国山 $\mathrm{S}$ : 猿投山 $\mathrm{KA}$ : 勘八峡 $\mathrm{A}$ : 足助 $\mathrm{TY}$ : 豊田盆地 $(\mathrm{TY}):$ 豊田峡谷 $\mathrm{OK}:$ 岡崎 $\mathrm{NI}:$ 西尾

河床堆積物のサンブリング位置 No.

庄内川 1. 瑞浪盆地 2. 土岐盆地 3. 多治見盆地 4. 高蔵寺上流側 5 . 高蔵寺下流側 6. 玉野峡谷

矢作川 1. 梅坪(豊田盆地上流側) 2 2. 久澄橋 (豊田盆地下流側) 3. 鵜の首 4. 細川 (平野 の頂点） 5. 矢作橋 (平野中央部) 6. 美矢井橋 7. 㠇塚 8. 八ッ面

Fig. 1 General map of the Shonai and Yahagi river basins

Shonai river U: Yudachiyama M: Mizunami basin (W): Wago gorge TO: Toki basin (TO): Toki gorge TA: Tajimi basin (T): Tamano gorge K: Kozoji N : Nagoya

Yahagi river O: Ohokawairiyama M: Mikuniyama S: Sanageyama KA: Kampachikyo A: Asuke. TY: Toyota basin (TY): Toyota gorge OK: Okazaki NI : Nishio

Sampling locality of the sediments

Shonai river 1. Mizunami basin 2. Toki basin 3. Tajimi basin 4. upper Kozoji plain 5. lower Kozoji plain 6. Tamano gorge

Yahagi river 1. Umetsubo(upper reach of the Toyota basin) 2. Kyucho bridge(lower reach of the Toyota basin) 3. Unokubi 4. Hosokawa(apex of the plain) 5. Yahagi bridge(central plain) 6 . Miyai bridge 7. Washizuka 8. Yatsuomote 
II 地形要素およびその組合わせから見た庄内川, 矢作川の特色

\section{1) 流域概観}

庄内川は岐阜県恵那郡夕立山 $(727 \mathrm{~m})$ に源を発し， 北西流して瑞浪盆地に入り, 方向を転し，屏風山断 層に平行して西南西へ流れ, 和合峡谷, 土岥盆地, 土岐峡谷, 多治見盆地, 玉野峡谷を経て高蔵寺で濃
尾平野へ入る. その後, 庄内川は名古屋市を北部か ら西部一迁回し，瀬戸方面からの矢田川を合流し， 伊勢湾へ注ぐ. 水源 高蔵寺は山地地域, 高蔵寺よ り下流が平野地域である(第 1 図).

矢作川とは猿投山 $(629 \mathrm{~m})$, 三国山 $(701 \mathrm{~m})$ を連ね る分水嶺により，また木曾川とは $300 ４ 00 \mathrm{~m}$ の美濃 高原で境する. 流域の地質は上流の屏風山断層付近 では濃飛流紋岩, 新期細粒花崗岩, 庄内川沿岸では

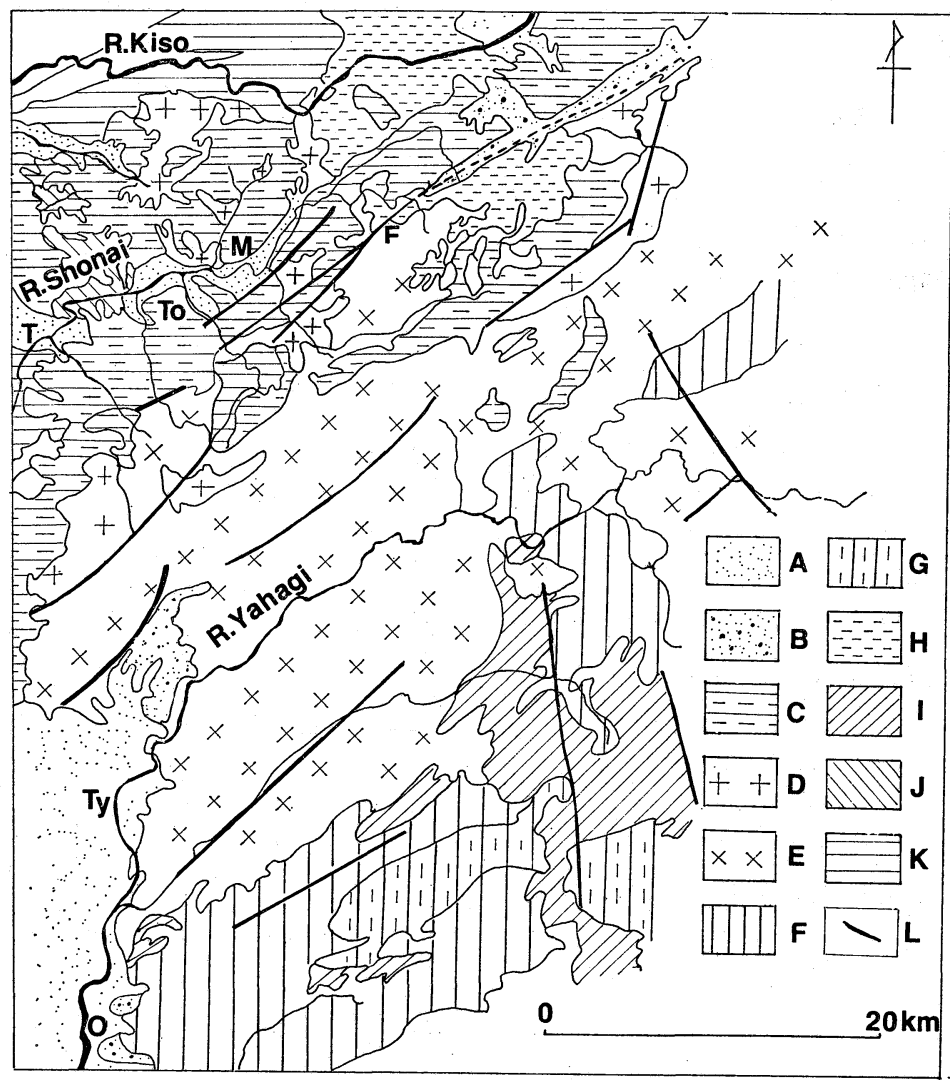

第 2 図庄内川, 矢作川流域地質図

$\mathrm{A}$ : 沖積層 $\mathrm{B}$ : 更新世堆積層 $\mathrm{C}$ : 新第三系 $\mathrm{D}:$ 新期花崗岩類 (細粒) $\mathrm{E}:$ 新期花崗岩類 (粗粒) $\mathrm{F}$ : 新期花崗岩類 (中粒) $\mathrm{G}$ : 古期花崗岩類 (中粒) $\mathrm{H}$ : 濃飛流紋岩 $\mathrm{I}$ : 領家変成岩類 $\mathrm{J}$ : 古生 層 (チャート) $\mathrm{K}$ : 古生層(粘板岩および砂岩) $\mathrm{L}:$ 断層

$\mathrm{T}:$ 多治見 $\mathrm{To}$ : 土岐 $\mathrm{M}:$ 瑞浪 $\mathrm{F}$ : 屏風山断層 $\mathrm{Ty}:$ 豊田 $\mathrm{O}:$ 岡崎

(地質調查所：『中部地方領家带地質図(1974)』を簡略化して作成).

Fig. 2 Geological map of the Shonai and Yahagi river basins

A: alluvium $B$ : pleistocene series $C$ : neogene system $D$ : younger granites(finegrained) E: younger granites (coarse-grained) F: younger granites(medium-grained) $\mathrm{H}$ : Nohi ryolites I: Ryoke metamorphic rocks $\mathrm{J}$ : paleozoic formation(chert) $\mathrm{K}$ : paleozoic formation(slate and sandstone) L: fault

T: Tajimi To: Toki M: Mizunami F: Byobusan fault Ty: Toyota O: Okazaki (Simplfied from "Geological Survey of Japan" (1974)). 
新第三系(第 2 図, C, D, E, H)からなり, 土岐, 瑞 浪付近では前記岩石を被覆して土岐砂礫層が分布す る.

矢作川は長野県伊那郡大川入山 $(1,908 \mathrm{~m})$ に源を 発し, 南西へ流れ, 勘八峡を経て豊田盆地に入る. その後, 豊田峡谷を経て細川で西三河平野に入り, 岡崎で乙川を合流して知多湾へ注ぐ．流域の地質は 主に上流が古期花崗岩, 中流が新期細粒花崗岩, 下 流が領家変成岩からなる(第 2 図, D, G, I)，両河川 の地形，水文の概要を比較すると第 1 表となり，矢 作川の方が規模は大きい.

2）庄内川下流平野の地形の特色

〈扇状地〉庄内川は, 山地から平野への出口に温 帯多雨造山帯の河成平野で一般的に見られる扇状地 （大矢，1973)は形成されず，支川の内津川に形成さ れているだけである(第 3 図).

〈自然堤防〉神領付近の屈曲点には, 本川より分 派して再び本川に戻る 3 本の旧河道があり，この周 辺に自然堤防 (幅 $100 \mathrm{~m}$, 比高 $50 \sim 100 \mathrm{~cm}$ ) が発達する 下流側の勝川以南では新川の分岐点, 小田井, 枇杷 島, 岩塚, 下之一色などの屈曲点, 滑走斜面に小型 自然堤防 (幅 $500 \sim 600 \mathrm{~m}$, 比高 $50 \mathrm{~cm}$ ), 枇杷島付近 の右岸側にはかつての木曾川派川である五条川の自 然堤防 (幅700 800m, 比高約 $1 \mathrm{~m}$ ) が合流し, その 後, 大治より南西へ分派し, 海岸へ向かう. 左岸側 では則武から中川運河および烏森を経て海岸に至る
数条の自然堤防が分布する(第 4 図).

〈デルタ〉 デルタは名古屋市北部の西志賀から庄 内川右岸の小田井, 春日の連なる海抜 $5 \mathrm{~m}$ の等高線 より下流側に形成され，地盤高と勾配から大治～岩 塚〜熱田以北の高位デルタ，以南の低位デルタに分 かれる(第 4 図)．縦断勾配は高位デルタ0.6/1,000, 低位デルタ $0.2 / 1,000$ (右岸側0.1/1,000) である.な お，熱田以南は 1,600 年以降の干拓地で大部分が 0 $\mathrm{m}$ 以下, 名古屋港周辺は明治以降の埋立地で海抜約 $2 \mathrm{~m}$ である. 平野部本川流長は $36 \mathrm{~km}$, デル夕占有 率は $1 / 2$ である.

3）矢作川下流平野の地形の特色

〈扇状地的自然堤防〉矢作川下流平野は，概観す ると西尾〜吉良以北では等高線はほぼ同心円状に配 列し，扇状地に見えるが，縦断勾配は細川〜西尾で $0.8 / 1,000$ であり，一般的河成扇状地より公配は緩 い. 細川から放射状にのびる旧河道は一部が網状化 し，これに沿って自然堤防が分布する．自然堤防の 幅は一般に700 1,200m であるが，中には幅 1,000 〜 1,500m, 比高 $1 \sim 2$ 㒓するものもある(第 5 図). 自然堤防の構成物質は大部分が粗砂で，長径 $1 \mathrm{~cm}$ 程度の礫をまれに混在する. 矢作川は1605年に 碧海台地を開削し，現流路となったもので，それ以 前は矢作古川が本流であった．矢作古川では右岸側 に旧河道は放射状にのび，自然堤防は顕著である。 すなわち，この下流平野は等高線のみから見ると極

第 1 表 庄内川, 矢作川流域の諸元比較

Table 1. Data on the Shonai and Yahagi rivers

\begin{tabular}{|c|c|c|}
\hline & Shonai river & Yahagi river \\
\hline Height of stream source (m) & 727 & 1,908 \\
\hline Area of drainage basin $\left(\mathrm{km}^{2}\right)$ & 1,010 & 1,830 \\
\hline Length of main stream $(\mathrm{km})$ & 96 & 117 \\
\hline Estimated flood discharge $\left(\mathrm{m}^{3} / \mathrm{sec}\right)$ & $\begin{array}{c}4,500 \\
\text { (Biwajima) }\end{array}$ & $\begin{array}{r}6,400 \\
\text { (Iwazu) }\end{array}$ \\
\hline Maximum record of flood discharge $\left(\mathrm{m}^{3} / \mathrm{sec}\right)$ & $\begin{array}{c}2,350 \\
1957.8 .7 . \\
\text { (Biwajima) }\end{array}$ & $\begin{array}{c}\text { 3, } 410 \\
1959.9 .26 \\
\text { (Iwazu) }\end{array}$ \\
\hline
\end{tabular}

(Ministry of Construction, 1979). 


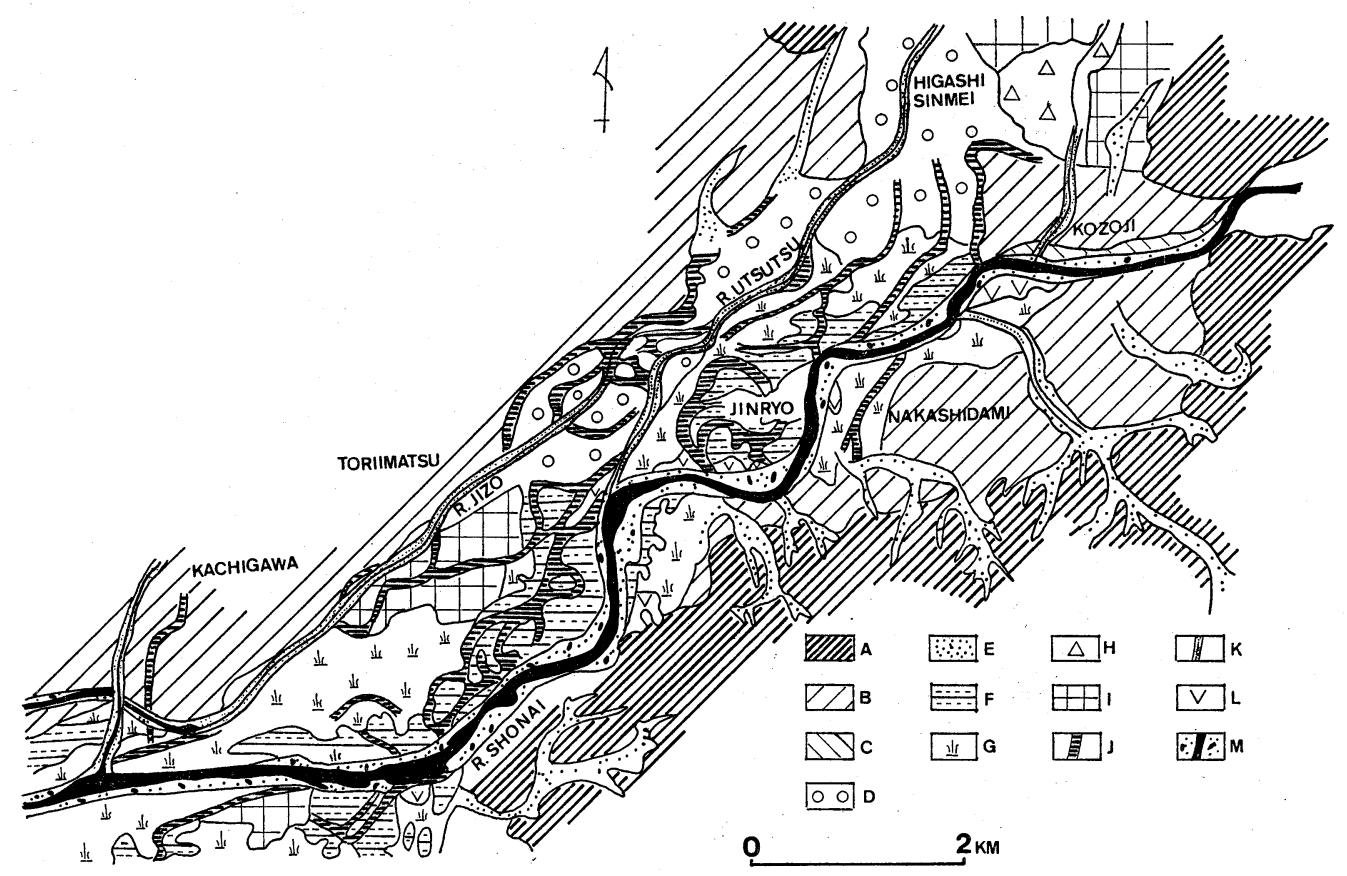

第 3 図庄内川下流域地形分類図(高蔵寺周辺)

$A$ : 山地 $B$ : 高位段丘 $C$ : 低位段丘 $D$ : 扇状地 $E$ : 谷底平野 $F$ : 自然堤防 $G:$ 後背湿 地 $\mathrm{H}$ : 土石流地形 $\mathrm{I}$ ：人工地形 $\mathrm{J}$ : 旧河道 $\mathrm{K}$ : 天井川 $\mathrm{L}$ ：破堤地形および「おっぽり」 $\mathrm{M}:$ 河川および河原

Fig. 3 Geomorphological map of the lower reach of the Shonai river basin (around Kozoji)

$A$ : mountain $B$ : upper terrace $C$ : lower terrace $D:$ fan $E$ : valley plain $F$ : natural levee $\mathrm{G}$ : back marsh $\mathrm{H}$ : topography formed by debris flow $\mathrm{I}$ : artificially filled up field $\mathrm{J}$ : former river course $\mathrm{K}$ : raised river course $\mathrm{L}$ : topography formed by bank collapse; erosional topography (pond so-called "Oppori") and depositional topography $\mathrm{M}$ : river and dry river bed

めて緩勾配の扇状地であるが，構成物質は粗砂であ り, 明瞭な自然堤防が発達し, 自然堤防と後背湿地 の組合わせ地域と見られるので，「扇状地的自然堤 防」と呼ぶことにした．このような地形が形成され たのは供給源の山地が風化しやすい花崗岩からなり， 平野頂点から西尾までほとんど粒径の変わらない粗 砂からなるためである.

〈扇状地的デルタ〉矢作川流域のデルタは西尾〜 貝吹より南側に分布し，デルタ地域の矢作古川の河 川流長は $34 \mathrm{~km}$, 下流平野でのデルタ占有率 $1 / 3$ で ある. デル夕の縱断勾配は $0.6 / 1,000 ，$ デルタ平野 における旧河道の蛇行は著しい.このデルタはほと んど全域砂質である. デルタは砂州の配列, 地盤高,
傾斜から花蔵寺〜長縄より北側の高位デルタ，南側 の低位デルタおよび油ヶ淵周辺の低位デルタに分け られる. 矢作古川沿いの低位デルタ上には吉良, 富 田，一色に海成砂州が発達する(第,5図)。デルタの 縦断勾配は高位面0.6/1, 000, 低位面0.5/1, 000で, 低位面前面に 1,600 年以降の干拓地が拡がる. 吉良 には，この地域最古の干拓地があり, 造成年代は, 1339年に遡る (大矢・杉浦1977). 矢作川下流右岸で は碧南干拓が, 1955 年に造成を終了し, 最低所は $-0.5 \mathrm{~m}$ である. 油ヶ淵低地では新川付替後に小規 模な砂州が形成された。このデル夕は扇状地的自然 堤防と同様に等高線は同心円状であり，一般的にデ ルタはシルト, 粘土で構成されるのに対して砂質で 


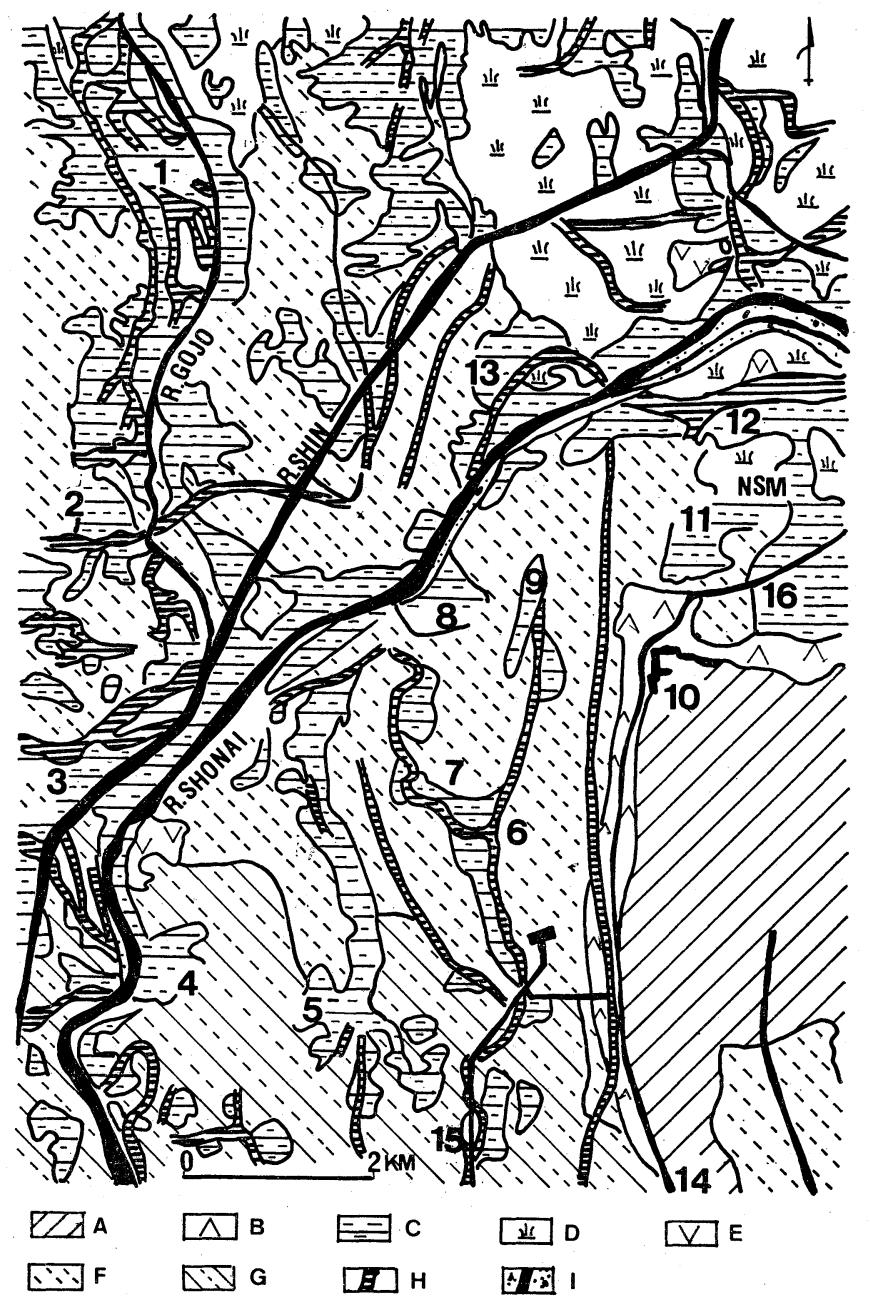

第 4 図庄内川下流域地形分類図 (名古屋周辺)

$\mathrm{A}$ : 段丘 $\mathrm{B}$ : 埋没波食台 $\mathrm{C}$ : 自然堤防 $\mathrm{D}$ : 後背湿地 $\mathrm{E}$ ：破堤地形および「おっぽり」

$\mathrm{F}$ : 高位デルタ $\mathrm{G}$ ：低位デルタ $\mathrm{H}$ : 旧河道 $\mathrm{I}$ ：河川および河原

1. 春日 2. 甚目寺 3. 大治 4. 岩塚 5. 烏森 6 . 名古屋 7. 則武 8. 枇杷島 9. 児

玉 10. 名古屋城 11. 西志賀 12. 光音寺 13. 小田井 14. 熱田 15. 中川運河 16. 黒

川 NSM : 西志賀貝塚

Fig. 4 Geomorphological map of the lower reach of the Shonai river basin(around Nagoya)

A: terrace $\mathrm{B}$ : buried wave-cut platform $\mathrm{C}$ : natural levee $\mathrm{D}$ : back marsh $\mathrm{E}$ : topography formed by bank collapse; erosional topography (pond so-called "Oppori")and depositional topography F : upper delta $\mathrm{G}$ : lower delta $\mathrm{H}$ : former river course $\mathrm{I}$ : river and dry river bed $\begin{array}{lllll}\text { 1. Haruhi } & \text { 2. Jimokuji } & \text { 3. Oharu 4. Iwatsuka 5. Karasumori } & \text { 6. Nagoya } & \text { 7. Noritake } 8 .\end{array}$ Biwajima 9. Kodama 10. Nagoya castle 11. Nishishiga 12. Koonji 13. Otai 14. Atsuta 15. Nakagawa canal 16. R. Kuro NSM: Nishishiga shell mound

あるので「扇状地的デルタ」と呼ぶことにする.

4）地形要素の組合わせから見た両平野の地域差 両平野の地形を比較するため, 地形要素の組合わ
せを模式化した(第 2 表)．この表には河成平野の地 形要素の組合わせの基本型(大矢, 1973) むあわせて 記した。 


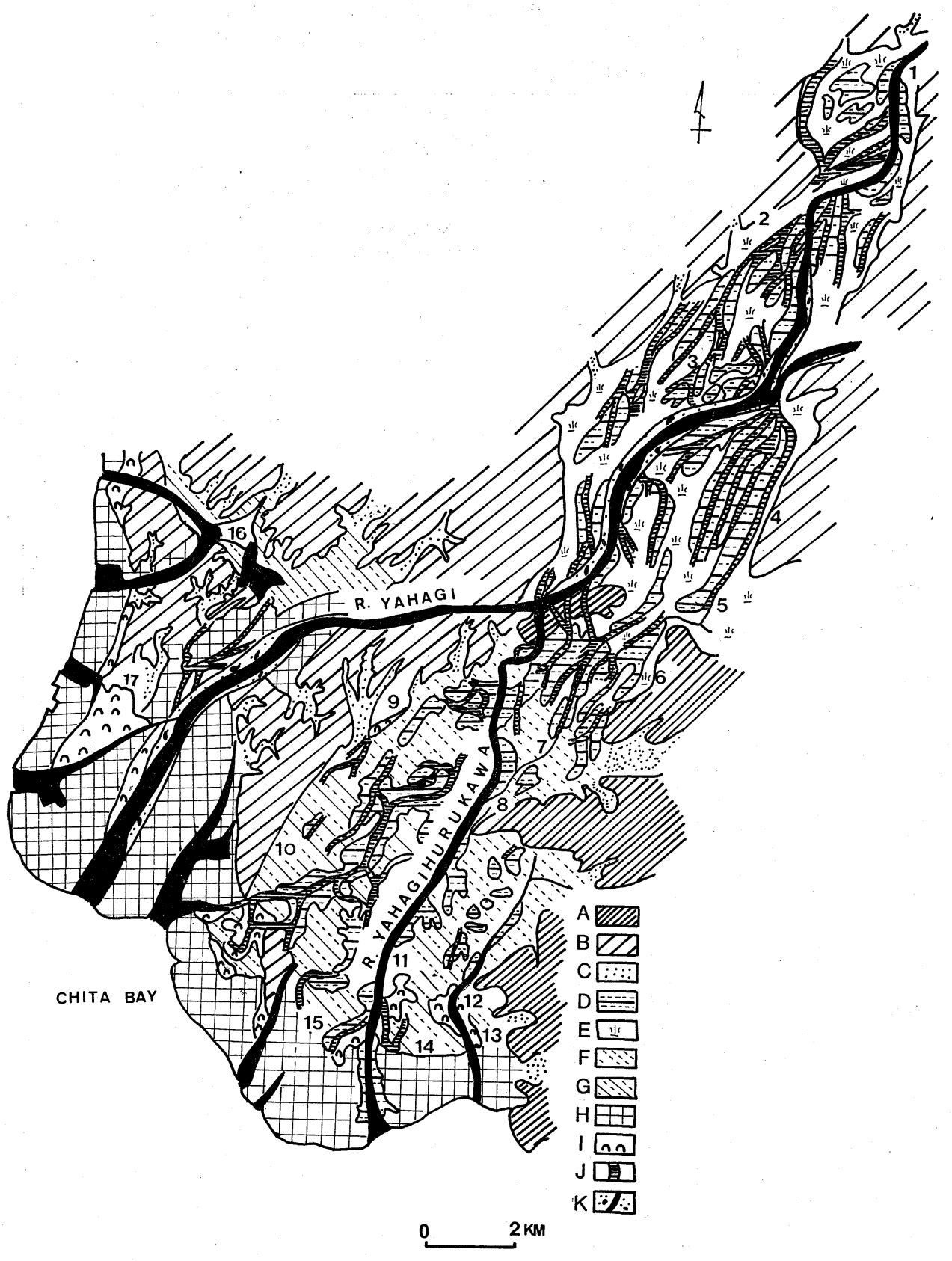

第 5 図矢作川下流域地形分類図

$\mathrm{A}$ ：丘陵 $\mathrm{B}$ : 段丘 $\mathrm{C}$ : 谷底平野 $\mathrm{D}$ : 自然堤防 $\mathrm{E}$ : 後背湿地 $\mathrm{F}$ : 高位デルタ $\mathrm{G}$ : 低位デルタ $\mathrm{H}$ :干 拓地 I : 砂嘴 $\mathrm{J}$ ：旧河道 $\mathrm{K}$ : 河川抢よび河原

1. 細川 2. 森越 3. 昭和 4. 岡崎 5. 占部用水 6. 釜田貝塚 7. 広田川 8. 花蔵寺 9. 西尾 10 . 長 縄 11. 富田 12. 饗庭 13. 吉良 14 . 吉田 15 . 一色 16 . 油ヶ淵 17. 碧南

Fig. 5 Geomorphological map of the lower reach of the Yahagi riverlbasin A: hill B: terrace $\mathrm{C}$ : valley plain $\mathrm{D}$ : natural levee $\mathrm{E}$ : back marsh $\mathrm{F}$ : upper delta $\mathrm{G}$ : lower delta $\mathrm{H}$ : reclaimed land $\mathrm{I}$ : sand spit $\mathrm{J}$ : former river course $\mathrm{K}$ : river and dry river bed 1. Hosokawa 2. Morikoshi 3. Showa 4. Okazaki 5. Urabe irrigation 6. Kamata shell mound 7. Kota river 8. Kesoji 9. Nishio 10. Naganawa 11. Tomita 12. Aiba 13. Kira 14. Yoshida 15. Ishiki 16. Aburagafuchi 17. Hekinan 
第 2 表 庄内川, 矢作川両平野の地形要素の組合わせ

Table 2 Geomorphological elements of the Shonai and Yahagi river basin

\begin{tabular}{l|c}
\hline Shonai river & $\begin{array}{c}\text { N. L. (Kiso river) } \\
\downarrow\end{array}$ \\
\hline Yahagi river & Fan-like N. L. + fan-like upper d. + fan-like lower d. \\
\hline Basic form is expressed by F. +N. L. +D. \\
F.: fan N. L. : natural levee n. l.: small natural levee D.: delta \\
d.: small delta
\end{tabular}

両平野の共通点は本川に明瞭な扇状地を欠くこと である．相違点は (1)庄内川は支川に扇状地をもつ が，矢作川では支川にも扇状地がない，(2)自然堤 防は庄内川で小規模, 矢作川で大規模に発達してい ること，(3) 自然堤防地帯では庄内川は木曾川の干 渉を受けるが，矢作川は他川の干渉がない，(4)旧 河道は庄内川では本川から分派しても下流側で再び 本川へ戻るが，矢作川は放射状で一部網状化し，扇 状地的様相を呈す，(5)デルタ面積の平野における 占有率は庄内川が高く, 矢作川で低い, (6)デル夕 の縦断勾配は庄内川は緩く，矢作川は急である。

\section{III 平地地形の地域差をもたらした原因}

\section{1）山地地形および砂碩生産}

従来, 山地起伏の計測には単位面積あたりの最高 点と最低点の高度差で定義される起伏量を用いたた め, その地域の特異な点を計測してしまうことも起 こり得た.たとえば準平原地域では残丘頂部と谷底 との比高を計測してしまうこともあり, 最も広く分 布する平坦面が表現されない次点があった，そこで， 今回は Ohomori (1978) の提唱した方法を利用した。 すなわち，1/50,000地形図に流域界を記入し，全流 域に一辺 $250 \mathrm{~m}$ のメッシュをかけ，その交点高度を 読み取り, 単位区画 $\left(1 \mathrm{~km}^{2}\right)$ の高度分布, 高度頻度, 高度分散量を計算し，あわせてブロックダイアグラ ムを描いた(第 3 表，第 6 図).

庄内川, 矢作川両流域の上流域では南西一北東方 向, 南東一北西方向の構造線が顕著にあらわれてい
第 3 表 庄内川, 矢作川流域の地形比較

Table 3 Comparison of the topography between the Shonai and Yahagi river basin

Shonai river $\quad$ SD: $30.8 \quad$ SDR : 28.56

\begin{tabular}{l|r|r|r|r|r}
\hline \multicolumn{1}{c|}{ tributaries } & \multicolumn{1}{c|}{ L } & \multicolumn{1}{c|}{ I } & \multicolumn{1}{c|}{ DB } & MA & MR \\
\hline Shonai & 96 & 5 & 1,013 & 234 & 84 \\
Sasaragi & 13 & 15 & 42 & 433 & 121 \\
Ori & 23 & 16 & 109 & 453 & 114 \\
Hida & 14 & 19 & 40 & 350 & 113 \\
Tsumaki & 15 & 20 & 37 & 308 & 118 \\
Kasahara & 18 & 17 & 37 & 243 & 95 \\
Jabora & 10 & 35 & 63 & 242 & 108 \\
Yada & 40 & 8 & 107 & 121 & 74 \\
Tsukiyoshi & 9 & 23 & 30 & 275 & 64 \\
Oohara & 5 & 15 & 19 & 181 & 53 \\
\hline
\end{tabular}

\begin{tabular}{l|r|r|r|r|r} 
Yahagi river & \multicolumn{2}{c}{ SD: 52.4} & \multicolumn{3}{c}{ SDR: 151.6} \\
\hline tributaries & \multicolumn{1}{c}{ L } & \multicolumn{1}{c}{ I } & \multicolumn{1}{c}{ DB } & MA & MR \\
\hline Yahagi & 137 & 9 & 1,832 & 450 & 115 \\
Ota & 38 & 13 & 254 & 400 & 120 \\
Tomoe & 61 & 12 & 347 & 450 & 137 \\
Asuke & 14 & 49 & 41 & 510 & 175 \\
Kago & 13 & 11 & 59 & 230 & 75 \\
Sanage & 9 & 27 & 18 & 200 & 55 \\
Kize & 10 & 29 & 29 & 340 & 105 \\
Inubuse & 11 & 16 & 63 & 370 & 103 \\
Azuri & 18 & 29 & 40 & 420 & 135 \\
Dando & 24 & 33 & 49 & 855 & 177 \\
Nagura & 25 & 16 & 92 & 850 & 178 \\
Kamimura & 35 & 40 & 216 & 1,000 & 193 \\
Ai & 20 & 43 & 25 & 1,330 & 212 \\
\hline
\end{tabular}

$\mathrm{L}$ : 河川長 $(\mathrm{km}) \mathrm{I}$ : 傾斜 $\mathrm{DB}$ : 流域面積 $\left(\mathrm{km}^{2}\right) \mathrm{MA}$ ： 平均高度 $(\mathrm{m}) \mathrm{MR}$ : 平均起伏 $\mathrm{SD}$ : 高度分散量 $\mathrm{SDR}$ : $\mathrm{SD}$ からの侵食量推定值

$\mathrm{L}$ : length of river $(\mathrm{km}) \quad \mathrm{I}$ : incline $\mathrm{DB}$ : drainage basin $\left(\mathrm{km}^{2}\right)$ MA : mean of altitude (m) MR : mean of relief $\left(\mathrm{m} / \mathrm{km}^{2}\right)$ SD: dispersion of altitude SDR: $\mathrm{SD}^{\mathrm{a}} \times 0.5993 \times 10^{-3}(\mathrm{a}=3.1426)$ 


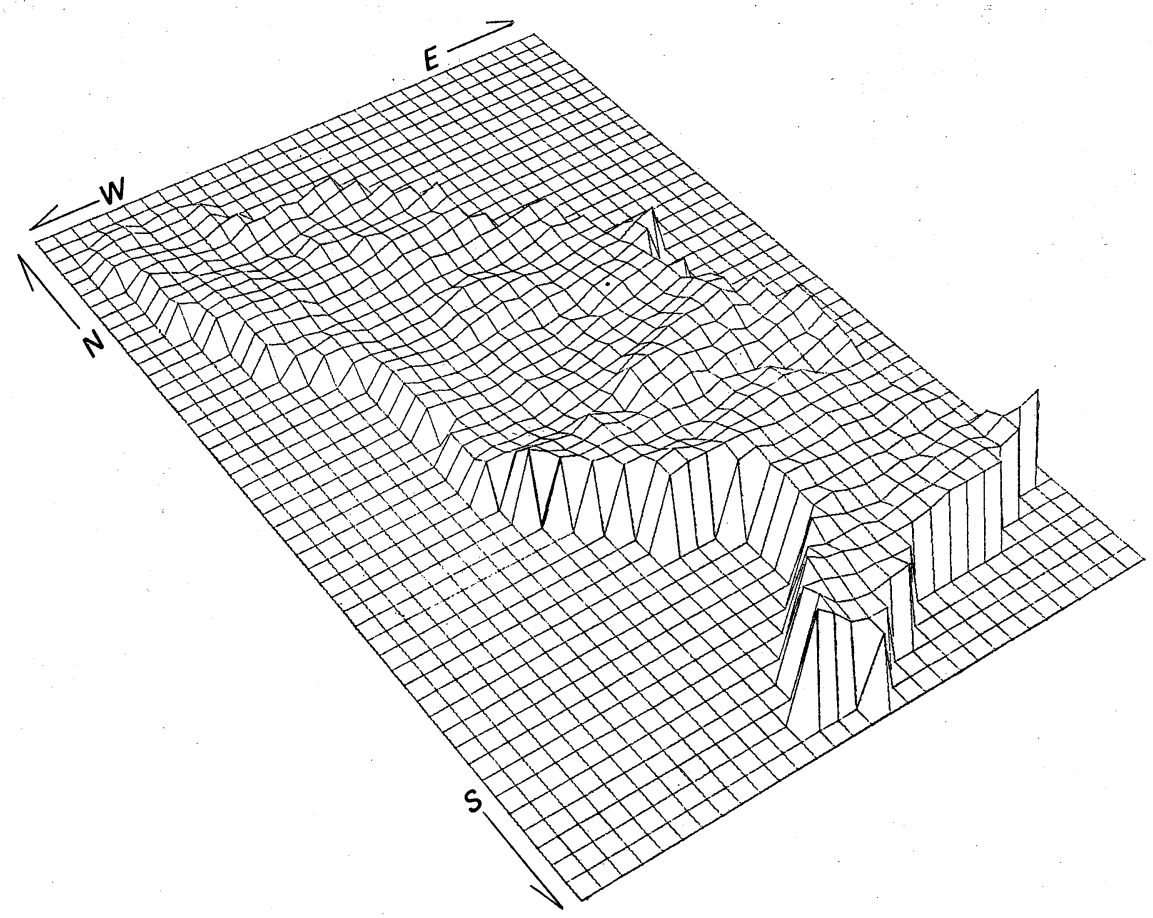

第 6 図＼cjkstart妻木川流域ブロックダイアグラム

妻木川流域南北 $12.25 \mathrm{~km}$, 東西 $8 \mathrm{~km}$ の地域に, $250 \mathrm{~m} \times 250 \mathrm{~m}$ のメッシュをかけ交点高度を読 みとった. 対象地域の地上主点 $O x=3,875 \mathrm{~m}, O y=6,000 \mathrm{~m}$ とし, $l y=20,000 \mathrm{~m}, z=20,000 \mathrm{~m}$ (画像の基底面高度 $100 \mathrm{~m}$ ), 俯角 $=44.9^{\circ}$, 平面に対する高さの倍率 3 で描いたもの.

Fig. 6 Block diagram of the Tsumaki river basin

る. 両河川の主な支川流域の平均高度, 高度分散量 は第 3 表に示したとおりで, 矢作川流域の方が数值 が大きい. すなわち, 高度分散量は矢作川 52.4 , 庄 内川30.8であり, 高度分散量から推定される河川の 侵食量の理論值も矢作川 151.6 で庄内川 28.56 より 大きいことがわかった. Ohomori (1978) は高度分 散量と侵食量の相関関係が大きいことを確かめた. 従って, 第 3 表より矢作川流域の方が山地崩壊発生 の素因が大きいことがわかる．矢作川では豊田盆地 上流の矢作ダムで，1971年のダム建設後10年間の砂 礫流入総量は $2,703,599 \mathrm{~m}^{3}$ であった(建設省矢作ダ ム資料). 支川から本川への土砂流出率は両河川と もほほ50\%を示している1。.

また，砂礫生産は地質と密接な関係がある．庄内 川流域では屏風山断層付近に花崗岩, 本川沿いに新
第三系, 古生層が分布している. 砂防地迄りセンタ 一 (1977)によると, 大原川, 高田川, 生田川, 妻木 川の各流域の瀬戸層群, 古生層に崩壊が多い. しか し，庄内川流域の崩壊は矢作川流域の崩壊より少な W.

豊田盆地以北の矢作川上流域では，本川右岸側は 最も深層風化の激しい新期粗粒花崗岩で，小原村 $300 \mathrm{ha}$, 明智町 $200 \mathrm{ha}$ ，藤岡村 $270 \mathrm{ha}$ (林野庁, 1980) の崩壊地が見られる.これは上記の花崗岩が細粒花 崗岩と比べて風化しやすいためである．本川右岸側 の飯田洞, 阿岳谷付近は花崗岩の節理が発達し, 降 雨で侵食をうけ，未風化部分が岩塊の形で崩落し， 河床に至る所で堆積している.

このように地形，地質ともに矢作川の方が崩壊発 生の素因は大であり, 最近発生している崩壊地も大 
きく, 河床への砂砂の供給量が大きい.

2）河床縦断面型と盆地, 峡谷の有無

上流山地で供給された砂䃯の下流平野までの運搬 は河川縱断面型および盆地, 峡谷の有無と密接な関 係をもっている(大矢, 1974).

庄内川本川の平均河床縱断勾配は5. $3 / 1,000$ (水源 ～河口)と緩やかである. 流路途中には瑞浪，土岐， 多治見の盆地および盆地間, 盆地と平野の間には長 、峡谷 (玉野峡谷 $11 \mathrm{~km}$, 土岐峡谷 $5 \mathrm{~km}$ ) が存在す る. 横断面型では谷は壮年期を呈している.

矢作川本川の平均河床綻断勾配は $9.2 / 1,000$ (水源 〜河口)であり庄内川より急勾配である. 山地から 平野にかけて盆地は豊田盆地が一つ存在するだけで,
峡谷の長さは $2 \mathrm{~km}$ と短く, 谷の横断面型は晚壮年 期を呈する.

河川の峡谷での侵食作用, 盆地での堆積作用を知 るため, (a )河川の最大の掃流力を表わすと考えら れる河床礫の最大礫の岩種別最大粒径, Krumbein の基準による円磨度測定，（b )50 150 kg の砂礫を

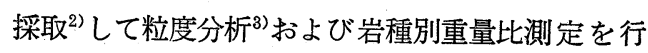
なった、サンプリング地点は第 1 図に，測定結果は 第 4 表, 第 5 表, 第 7 図に示した.

最大礫では全ての岩種で粒径は玉野峡谷が最大, 土岐盆地，多治見盆地は上流にあるにもかかわらず 小さい，円磨度は玉野峡谷では大，小が混在する. 平均粒径では土岐盆地(No. 2)で小さかったものが,

第 4 表 庄内川, 矢作川の峡谷, 平野における最大礫径の変化

Table 4. Changes of the maximum grain size in the gorge and plain in the Shonai and Yahagi rivers

Shonai river

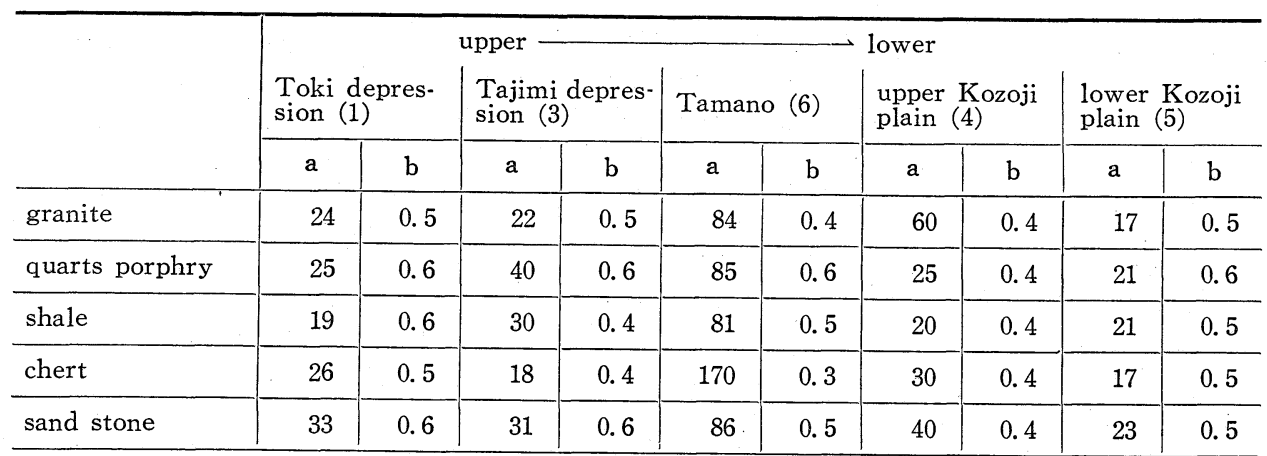

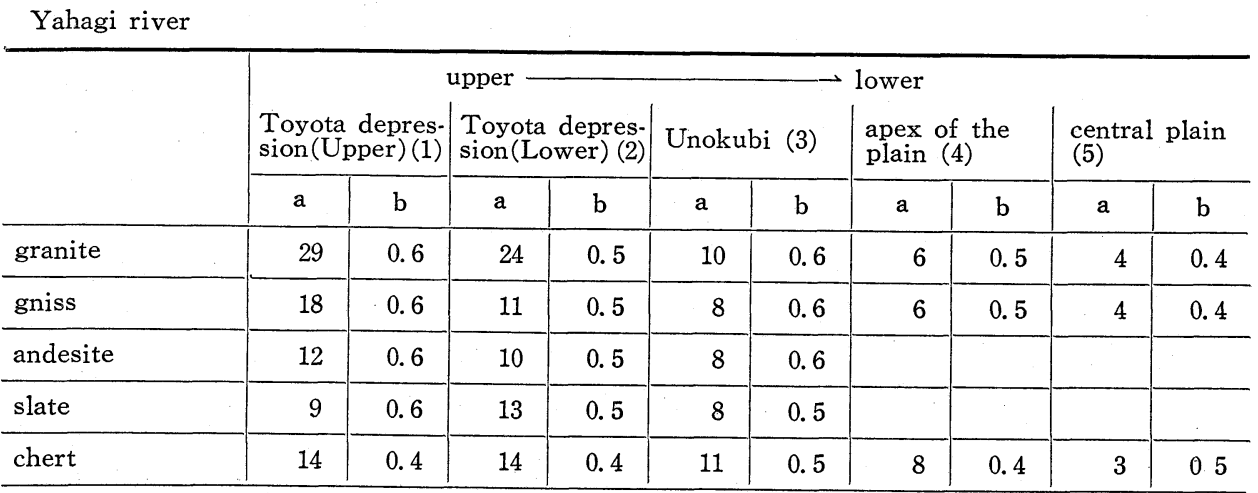

$\mathrm{a}$ ：最大粒径 $(\mathrm{cm}) \quad \mathrm{b}:$ Krumbein の基準による円磨度 （1 5)：サンプリング位置 (第 1 図参照) a : maximum diameter $(\mathrm{cm})$ b: roundness by Krumbein $(1 \sim 5)$ : sampling localities (refer to Fig. 1) 
第 5 表 庄内川, 矢作川の河床堆積物の平均粒径, 粒径の分散度および歪度

Table 5 Mean diameter, standard deviation and skewness of the sediments in the Shonai and Yahagi rivers

Shonai river

\begin{tabular}{c|l|l|l|l}
\hline No. & $\mathrm{Md} \phi$ & $\mathrm{M} \phi$ & $\delta \phi$ & $\alpha \phi$ \\
\hline 1 & -7.6 & -7.4 & 1.3 & 0.18 \\
2 & -5 & -4.5 & 3.45 & 0.33 \\
3 & -7 & -6.8 & 0.8 & 0.16 \\
4 & -6.6 & -5.7 & 1.75 & 0.47 \\
5 & -4.8 & -4 & 1.9 & 0.3 \\
\hline
\end{tabular}

Yahagi river

\begin{tabular}{c|l|l|l|l}
\hline No. & $\mathrm{Md} \phi$ & $\mathrm{M} \phi$ & $\delta \phi$ & $\alpha \phi$ \\
\hline 1 & -7.2 & -7.1 & 0.9 & 0.09 \\
2 & -6.5 & -6.3 & 0.7 & 0.16 \\
3 & -5.5 & -5.35 & 0.85 & 0.13 \\
4 & -3.2 & -3.7 & 1.3 & 0.62 \\
5 & -0.8 & -1.15 & 1.35 & 0.43 \\
6 & -1.6 & -1.75 & 1.75 & 0.16 \\
7 & -0.2 & -0.65 & 1.15 & 0.57 \\
8 & -0.6 & -0.9 & 0.9 & 0.1 \\
\hline
\end{tabular}

$\phi:-\log _{2} \mathrm{y} \operatorname{Md} \phi:$ 累加曲線 $50 \%$ の值 $\mathrm{M} \phi$ : 中央值 $\delta \phi:$ 分散度 $\alpha \phi:$ 歪度

$\phi:-\log _{2} \mathrm{y} \quad \mathrm{Md} \phi: 50 \% \quad \mathrm{M} \phi:\left(\phi_{16}+\phi_{84}\right) / 2 \quad \delta \phi:\left(\phi_{84}\right.$ $\left.-\phi_{16}\right) / 2$ standard deviation $\alpha \phi:\left(\phi_{25}+\phi_{75}-2 \mathrm{Md} \phi\right) \mid$

2 skewness

土岐峡谷 (No. 2 No. 3 間)を下り, 多治見盆地 (No.

3)で大きくなり, 高蔵寺下流(No.5) 上り漸减する.

また, 礫の岩種類別重量比(第 7 困) は瑞浪盆地で 花崗岩, 安山岩, 斑岩などの火成岩が50\%を示すが, 下流の高蔵寺では減少し, 砂岩, 礫岩, チャートな どの堆積岩が増加する. 粒度分析結果より, 庄内川 では上流山地からの供給砂磷は全てが下流平野まで 達するのでなく, 細礫, 砂など細粒物質を除くかな りの量の礫が盆地末端部で停止, 堆積し, 峡谷特に 玉野峡谷で，新たな岩屑供給を受けることもわかっ た．また，笠原川他多治見盆地へ注ぐ支川の砂磁供 給量は多い。

庄内川縦断面 (第 8 図) では玉野峡谷に遷急点 $\mathrm{W}_{1}$, 土岐峡谷に小規模遷急点 $\mathrm{W}_{2}$ があり, 緥断勾配は峡 谷で急, 盆地で緩やかとなっている ${ }^{4)} \mathrm{W}_{1}$ より下 流, $\mathrm{W}_{2}$ より上流の縦断面では, 共に上流が急で下
流が緩やかな凹曲線となり遷急点はない，最大礫の 粒径はこの縱断曲線にほほ対応し，急勾配地域で大， 緩勾配地域で小となっており, 遷急点を境に上流側, 下流側で河川はほぼ平衡状態に達していると考えら れる(大矢，1954)．すなわち，二つの平衡曲線の境 界に $\mathrm{W}_{1}, \mathrm{~W}_{2}$ が形成されている. そこで上流山地で の供給砂礫の大粒径のものは, 大部分が緩勾配の土 岐盆地, 多治見盆地で堆積し, 遷急点をこえて下流 平野まで達するのは，小粒径の砂磉と玉野峡谷で供 給された岩霄が砂礫となったもので, その量は多く ない，これが下流平野に扇状地を形成しない原因の 一つである.

矢作川での粒径は豊田峡谷では増大せず，上流〜 下流へ漸減するが, 豊田盆地と下流平野で最大粒径, 平均粒径に顕著な差が認められる，すなわち，豊田 盆地(第 7 図, 1 3)では $-6 \phi$ 以上の礫が多く, 平 野部(第 7 図, 4 8)では $-2 \phi$ 以下の礫が大部分を 占める. $-6 \phi$ 以上の礫は豊田盆地に堆積し, 砂, 細礫となったものは豊田峡谷を通過するが，その際 に新たな岩屑の供給はない，岩種別重量比から，上 流で供給された花崗岩礫が盆地末端に到達するまで に細礫となり，下流平野では $-6 \phi$ 以下の細礫，砂 となることがわかる.ただ，平野最上流部(第7図，

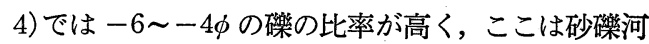
川から砂河川への漸移帯であり，砂，礫を共に運搬 しうる異なる二つの運搬機構をもつ地域である.

矢作川は水源 $＼mathrm{~ 大 野 の 急 勾 配 凹 曲 線 ， 大 野 ~ 豊 田 ~}$ 峡谷の小規模な 4 カ所の遷急点をもつ区間，豊田峡 谷〜河口の緩勾配直線状縦断曲線の 3 区間をつない だ河床緃断曲線を示している. 上流では急勾配, 両 岸からの多くの花崗岩の砂礫供給で, 多量の砂䃯が 豊田盆地に達している.

平野部の河床砂碰は小礫を含む花崗岩起源の粗砂 からなるが，この花崗岩は粗粒花崗岩で鉱物粒子が 大きく, $2 \phi$ 以下に細粒化しない特殊性をむつ(谷津, 1954)。また，平野部ではどの地点でも砂砂流動が 
SHONAI R.

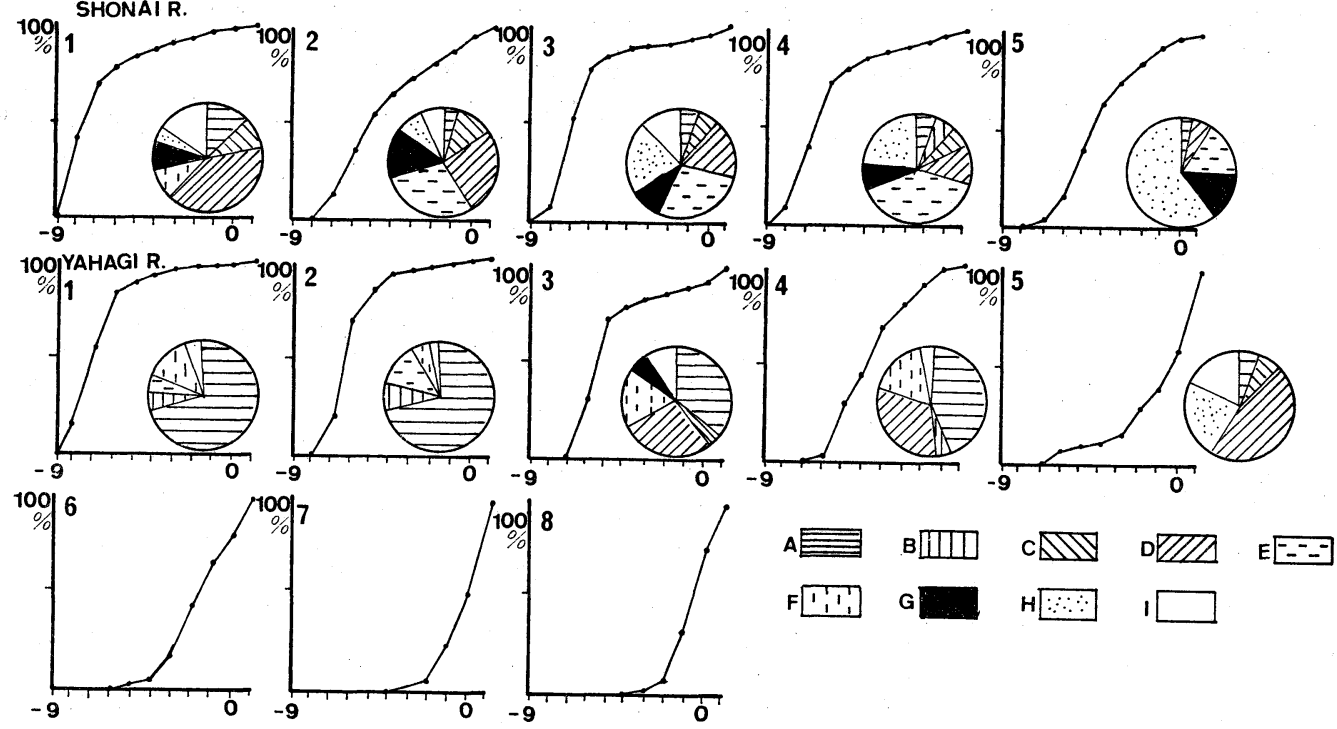

第 7 図庄内川，矢作川の河床堆積物の累加頻度おょび岩種別比率

$\mathrm{A}$ : 花崗岩 $\mathrm{B}$ : 安山岩 $\mathrm{C}$ : 斑岩 $\mathrm{D}$ : 石英斑岩 $\mathrm{E}:$ チャート $\mathrm{F}$ : 変成岩 $\mathrm{G}$ : 堆積岩 $\mathrm{H}$ : 砂岩 $\mathrm{I}:$ 不明 Shonai river $1.133 .2 \mathrm{~kg} \quad 2.109 .2 \mathrm{~kg} \quad 3.118 .17 \mathrm{~kg} \quad 4.143 .7 \mathrm{~kg} \quad 5.55 \mathrm{~kg}$

Yahagi river $\quad 1.115 .3 \mathrm{~kg} \quad 2.70 \mathrm{~kg} \quad 3.68 \mathrm{~kg} \quad 4.56 \mathrm{~kg} \quad 5.58 \mathrm{~kg} \quad 6.51 \mathrm{~kg} \quad 7.46 \mathrm{~kg} \quad 8.48 \mathrm{~kg}$

Fig. 7 Cumulative curve of the sediments and ratio of the rocks in the Shonai and Yahagi rivers

A: granite B: andesites C: porphyrite D: quartz-phorphyry E: chert F: schist $\mathrm{G}$ : conglomerate $\mathrm{H}$ : sandstone $\mathrm{I}$ : unknown

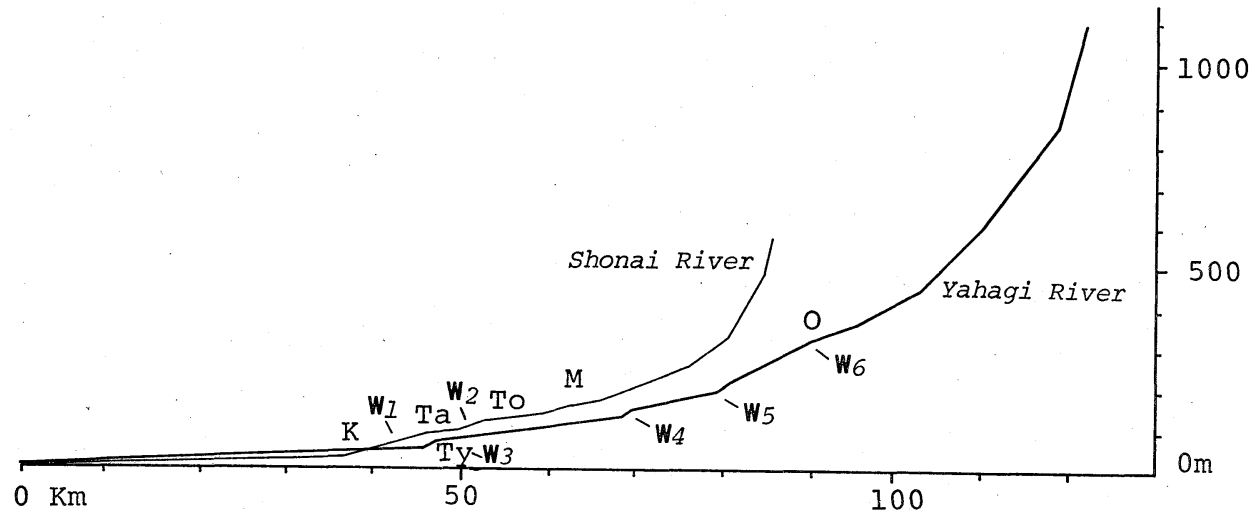

第 8 図庄内川，矢作川の河川縦断図

庄内川 $K$ : 高蔵寺 $T:$ 多治見 $T o:$ 土岐 $M$ : 瑞浪

矢作川 $\mathrm{Ty}:$ 豊田 $\mathrm{O}:$ 大野

$\mathrm{W}_{1-6}$ : 遷急点

Fig. 8 Longitudinal profiles of the Shonai and Yahagi rivers

Shonai river K: Kozoji T: Tajimi To: Toki M: Mizunami

Yahagi river Ty: Toyota O: Ohno

$\mathrm{W}_{1-6}$ : knick point 
激しく, 1 回の洪水で河床表面から $30 \mathrm{~cm}$ 程度の深 さの砂層が入れ替わってしまうほどである.このよ うに，絶えず上流から大量の砂が供給され，しかも 一定粒子以下に細粒化しないため，平野部の河床は 上流から下流までほぼ同一粒径の砂層となる.これ は, 下流平野の縦断曲線が凹曲線でなく直線状を呈 する一因となると考えられる. また，平野での扇状 地, 自然堤防，デル夕の地形区分がそれほど明瞭で なく, 平野全体が極めて緩傾斜, 砂質扇状地的地形 となったと解釈される.

3）縄文海進堆積物を被覆する河成沖積層の前地 形と層厚

日本の海岸平野では，一般に縄文海進期の海成層 上に河川による砂砂の堆積層がある. 砂礫堆積は主 に洪水時に行なわれ，この汇濫範囲は平野を限る山 地，段丘などに制約される．そこで, 縄文海進期の 海成層を被覆する河成沖積層堆積の前地形(平井, 1983)およびその層厚について両河川流域を比較し た.

縄文海進時の海成層は庄内川では河口から, 右岸 側に $18 \mathrm{~km}$, 左岸側に $14 \mathrm{~km}$, 矢作川では左右両岸 とも河口から $16 \mathrm{~km}$ 地点まで分布している. 庄内川 での左右両岸の相違は東高西低の濃尾平野構造盆地 運動と関係していると思われる．海成層上の河成堆 積物の層厚は庄内川では高位デルタで7.5 12.5m, 低位デルタで 2.5 8m である. 干拓地はこの層が 欠如し, 海成層が露出している. 矢作川での河成堆 積物はかなり厚く, 矢作古川河口付近で $10 \mathrm{~m}$ あり, 現河口付近の干拓地上にも砂の堆積が見られ, 縄文 海進後現在までの砂礫堆積量は庄内川より大きい．

汇濫原は庄内川では平野頂点の高蔵寺から名古屋 市北部までの間は幅 $1 \sim 2.5 \mathrm{~km}$ と細長く, 両側は段 丘で囲まれる. 名古屋市北部から枇杷島までは汇濫 原は東は熱田台地，その台地下の埋没波食台から西 側は木會川派川の五条川の自然堤防地帯までであり, 右岸側の氾濫原幅は狭い，一方, 矢作川は平野頂点
から河口まで両岸を段丘，山地に囲まれ，幅 2 4 $\mathrm{km}$ の帯状平野となっている.

この相違は, 庄内川が東高西低の地殼変動を行な っている濃尾平野を流れ，他川の干渉を受けるのに 対して, 矢作川は北高南低の地壳変動を行なってい る西三河平野を他川の干渉を受けることなく流下す ることによって生じたと考えられる.このように， 庄内川では汇濫範囲が狭いため, 扇状地, 自然堤防 の発達が悪い, 一方, 矢作川では自然堤防は放射状 に分派しており,これらは洪水型の相違となってあ らわれている。

4）洪水型と本支川による堆積

庄内川では, 高蔵寺〜春日井は段丘, 丘陵に汇濫 原を狭められ，更に右岸側は内津川扇状地に圧迫さ れる. 旧河道は本川から分派したものが $2 \mathrm{~km}$ も下 らないうちに合流する．破堤，氾濫がおきた場合は 本川より溢流した水は支川内津川の洪水に押され， また，段丘，丘陵で汇監範囲が狭められているので， 主として旧河道に沿って流下する，そして，堤内地 より堤外地へ破堤して再び本川へ流入する集中型と なっている (Oya, 1973). また，この時に破堤に時 間を要するので一時的な堤内地の湛水が扰きる貯留 型洪水でもある. 本川に直交方向の横断面では上流 に近い部分では本川沿いが周辺より低く, 庄内川が 沖積平野の侵食を行なっていることもわかる．矢田 川合流点〜大治町では右岸は木曾川派川の堆積に押 され，本川氾監範囲は新川の線までで幅 $1.5 \sim 2 \mathrm{~km}$ にすぎない，左岸は熱田台地までである．この地域 は中世まで河床が低く，洪水は集中型であった。 1601年以降臨海部での干拓により河道が延長し, こ れに伴い河床は上昇に転じ, 洪水は頻発, 溢流型と なった. 洪水の回数も16 19世紀初頭までに右岸18 回, 左岸 2 回と多かった(水野, 1982). 右岸の破堤 が多いのは矢田川合流による流量の増加, 小田井付 近が庄内川屈曲点の攻撃斜面にあたるなどの自然条 件に加光, 名古屋市防備のための人為条件が加わっ 
たためである.このため, 小田井付近の自然堤防形 成が促進された．また，右岸側には破堤により生じ た落堀とその周辺の砂質微高地の組合わせからなる 破堤地形も見られる. 新川は19世紀末に庄内川の洪 水流を排水させるために開削(水野，1982)されたも ので, 庄内川と新川を結ぶ水路にも庄内川洪水の際 に生じたと思われる破堤地形が形成されている.

大治より下流の低位デルタは他河川の干渉を受け ず，汇濫範囲は広い，洪水は溢流型で自由蛇行を繰 り返してきた．富田荘古図から大規模な河道変遷は 中世頃と推定される(安田, 1971). 自然堤防の発達 は小規模で比高は $1 \mathrm{~m}$ 以下である. 下之一色より下 流は，1601～1850年に造成された干拓地と1951年以 降の埋立地で，河道は直線状に固定されている．高 潮洪水に襲われる地域で自然堤防はなく, 表面から 海成層が露出している.

矢作川は豊田峡谷を出て平野に入ると南南西へ流 下する.1605年の碧海台地開削前は矢作古川を経て 海へ注いでいた，汇濫原幅は $2 \sim 4 \mathrm{~km}$ で細長く，谷 底平野状である，この幅は扇状地を発達させるには 不十分であるが, 庄内川の高蔵寺〜名古屋市北部よ りは広い. 本川の堆積が大きいため, 旧河道は集中 型ではなく，蛇行を直線状に切るか，本川に平行し て河口にまで達している. 豊田峡谷を出て, 森越〜 昭和町での矢作川の蛇行は著しいが，旧河道はこの 湾曲部を短絡する形で存在する. 昭和町で旧河道は 矢作川を横断し, 西尾南部, 長縄をへて知多湾へ注 ぐ(第 5 図).今一つの流路は乙川の流路で，岡崎西 部から占部用水に沿って流下し, 花蔵寺南部で狭い 谷を通過し，広田川に沿って流下する.これは1300 年代に六名堤が築かれ, 流路が西へ導かれ, 矢作古 川に合流させられたもので, これらの旧河道に沿っ て自然堤防が発達している.

旧河道, 自然堤防の分布から, 矢作川下流平野の 洪水型は昭和町で 2 分される. 上流側は，蛇行を短 く切る谷底平野で一般的に見られる洪水型である.
下流側は，本川より溢流した洪水は再び本川に合流 することなく海へ放水される溢流型である．これは 矢作川の天井川化と関連している.この型の洪水の 繰り返しで数本の自然堤防が矢作古川と平行して形 成された。

$$
\text { IV まとめ }
$$

筆者らは隣り合って流れる庄内川, 矢作川流域の 地形の比較研究を行なった. まず, 平野の地形分類 を行ない，その地形要素および組合わせの地域的特 色を明らかにした．次いで，その特色をもたらした 原因を砂磞生産地の山地地形, 砂砂を運搬する河道 形態, 特に縦断型と盆地, 峡谷の分布, 縄文海進堆 積物を被覆する河成沖積層の前地形, 洪水型と本支 川による堆積に求め, 調査を行なった。

両平野の地形要素の組合わせは次のとおりである. 〔庄内川小型自然堤防 +高位デルタ十低位デルタ 内津川扇状地 木曾川系自然堤防

〔矢作川〕扇状地的自然堤防＋扇状地的高位デルタ 十扇状地的低位デルタ

この相違をもたらした原因として次の諸点があげ られる.

（1）山地地形では平均高度, 平均起伏, 高度分散 量とも庄内川流域より矢作川流域の方が大であり， 侵食されやすい粗粒花崗岩の分布地域が広いため, 山地崩壊発生の素因は大きい，支川から本川への砂 礫流出率は両河川とも大差なく, 流域面積が広く, 支川の多い矢作川がより多くの砂礫を流出している.

(2)河床縦断勾配は庄内川が矢作川より緩やかで あり，かつ流路途中に盆地および遷急点をもつ峡谷 が繰り返し存在する.上流から運搬された砂礫は盆 地で停止し，小礫のみが下流へ流下する，峡谷では 岩屑が供給されるがその量は多くない：これは庄内 川に扇状地を発達させない一因となっている.

矢作川では本川に小型の豊田盆地が一つあるだけ で, しかも豊田盆地と平野を分ける峡谷の距離は短 
い. 上流から運搬される礫は主として粗粒花崗岩で, 粒径の大きいものは盆地に堆積する. 花崗岩は破砕 されやすい性質をもつが，同時に鉱物粒子は破砕さ れにくいため, 小礫混じり粗砂となり，大量に下流 平野へ流下する. 従って, 河床堆積物の粒度組成は 変化しない. このため, 扇状地, 自然堤防, デル夕 の境界は明瞭でなく，扇状地的自然堤防，扇状地的 デルタとなる.

（3）縄文海進堆積物を被覆する河成沖積層の前地 形では，基底をなす縄文海進時の海成層の分布範囲 は庄内川では右岸側は河口から $18 \mathrm{~km}$ まで, 左岸側 は14 km まで，矢作川では両岸とも $16 \mathrm{~km}$ までであ る. 海成層上の河成堆積物の層厚は庄内川では高位 デルタで $7.5 \sim 12.5 \mathrm{~m}$ ，低位デルタで $2.5 \sim 8 \mathrm{~m}$ であ る. 干拓地ではこの層は欠如し, 海成層は露出する. 矢作川では河川堆積物はかなり厚く, 矢作古川河口 付近で $10 \mathrm{~m}$ あり, 河口付近の干拓地上にも砂の堆積 が見られる．縄文海進後現在までの砂礫堆積は庄内 川より矢作川が大きい.

(4)これら砂礫の堆積が行なわれる氾濫原は山地, 丘陵，台地などに囲まれている．庄内川では平野上 流部の高蔵寺〜名古屋北部は段丘に囲まれ，幅は狭 く，約 $1 \mathrm{~km}$ にすぎない，名古屋北部より下流は広 い平野に出るが，大治までは木曾川系派川の堆積に より氾濫原の範囲は限定される.このため, 上流側 は旧河道が本川から分派し, 再び本川へ戻り, 洪水 流も旧河道に沿って流れる集中型(貯留型)となる. 中流は自然堤防の発達は右岸側で，破堤も右岸に多 く，本川からの溢流水は庄内川の自然堤防と木曾川 系自然堤防の間の後背湿地へ流入，湛水した．新川 開削により，排水はこれを伝わってなされるように なった．下流では段丘など汇濫範囲を制約するもの はなく，中世以来自由蛇行していた，堆積物は少な く, 自然堤防の発達は悪い.

矢作川では平野の頂点から海岸まで汇濫範囲は段 丘に限られ，幅 $2 \sim 4 \mathrm{~km}$ でほとんど変化がない，旧
河道分布から見ると，昭和町以北は蛇行部を直線状 に切る谷底平野型である. 下流側は本川の堆積が大 きく，天井川化しており，旧河道の分布は本川より 分派し, 放射状にのびて海岸に達する. 洪水汇濫時, 矢作川下流平野の上流側は蛇行を短く切って流れ， 下流側は溢流水が旧河道および後背湿地の最低所を 伝わって流下する.

本調查中, 多大の御援助を頂いた東京大学理学部大森 博雄助教授および建設省庄内川工事事務所, 豊橋工事事 務所の方々に厚く御礼申し上げます.

(投稿 1986年 2 月 17 日)

(受理 1986年6月14日)

\section{注}

1）矢作川では『昭和 47 年 7 月豪雨災害復興誌』 (愛知県, 1972), 庄内川では『庄内川砂防計画報 告書』(砂防地式り研究センター, 1977) より溪床堆 積物を流出量でわることにより算定した，矢作川 では $48 \%$ ，庄内川では $43 \%$ の流出がみとめられる.

2）粒度分析地点は水際より約 $1 \mathrm{~m}$ 離れ, 河原の状 態を代表する場所を選定し，砂礫を掘り出し，笁 分けを行なった．穊は $-8 \sim-1 \phi$ を用い, $-6 \phi$ 以上の碩は岩種別に分類，計量し，地点ごとに累 加曲線, 岩種別グラフを作成した.

3）ウェントウォースによる粒径区分を用いた。 大 砂は $-6 \sim-8 \phi$, 巨礫は $-8 \phi$ 以上のものである. 庄内川 No. 1 地点の巨磞は 4 個, 大礫は 49 個,

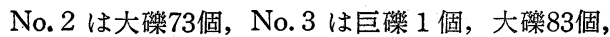
No. 4 は巨磞 1 個, 大磞 113 個, No. 5 は大礫 22 個，矢作川は No. 1 で巨磞 3 個，大磎88個，No.2 で大磎86個, No. 3 で大礫 39 個, No. 4 で大礫 40 個, No. 5 で大磷13個である。

4）玉野峡谷5.8/1,000，土岐峡谷6.7/1,000，多治 見盆地 $2.4 / 1,000$, 土岐盆地3. $2 / 1,000$.

\section{文献}

愛知県 $(1972):$ 『昭和 47 年 7 月豪雨災害復興誌』 248 ページ.

海津正倫 (1979)：更新世末期以降における濃尾平野 の地形発達過程, 地理評, 52, 199 208.

井関弘太郎 (1961)：矢作史料編・地形篇。岡崎市史 編さん委員会 :『岡崎市史』1 17.

井関弘太郎 (1980)：『愛知県の地質, 地盤その $3 \rrbracket$ 愛知県防災会議地震部会, 78ページ.

太田陽子・貝塚爽平 - 加藤芳朗 - 桑原 徹 - 白井哲 之・土 隆一・山田 純・伊藤通玄 (1963)：三河 
高原及びその西縁の段丘群. 地理 評，36，617〜 624.

大矢雅彦 (1971)：『中津事業区崩壊地形分類図』名 古屋営林局。

大矢雅彦 (1973)：沖積平野における地形要素の組合 せの基本型. 早稲田大学教育学部学術研究, 22, $22 \sim 43$.

大矢雅彦 (1974)：最上川における砂磁流動に対して 盆地, 峡谷のもつ意義. 東北地理, $26,1 \sim 14$.

大矢雅彦 (1982)：河川地理学序説. 三井嘉都夫教授 還暦事業会編 : 三井教授還暦記念論文集『環境科 学の諸断面』土木工学社, 1 4.

大矢雅彦・杉浦成子 (1977) :『矢作川下流平野水害 地形分類図』建設省豊橋工事事務所.

大矢雅彦・杉浦成子 (1979)：『庄内川治水地形 分類 図』建設省庄内川工事事務所.

貝塚爽平・木曽敏行 - 町田 貞・太田陽子・吉川虎 雄 (1964)：木會川，矢作川流域の地形発達. 地理 評, 37, 89 102.

木曾敏行 (1963) : 木曾川流域の地形発達. 地理評, 36, 87〜109.

桑原 徹 (1968)：濃尾盆地と傾動地塊. 第四紀研究, 7, 235 247.

砂防地迄り研究センター(1977)：『庄内川砂防計画 報告書』多治胃工事事務所, 214 ページ.

多田文男・井関弘太郎 (1955) :『濃尾平野の地形構 造と地盤沈下』総理府資源調查会, 97ページ.

平井幸弘 (1983)：関東平野中央部における沖積低地 の地形発達. 地理評, 56, 679 694.

松沢 勲・嘉藤良次郎 (1954)：『名古屋及び付近の 地質』愛知県建築部, 35ページ.

水野時二 (1982)：放水路新川の開さくとその意義. 建設省庄内川工事事務所編：『庄内川流域史』67 $\sim 72$.

森山昭雄 - 小沢 恵 (1972)：矢作川沖積地の地形と 沖積層. 第四紀研究，11，193～207.

森山昭雄 (1978)：矢作川平野表層堆積物の粒度組成. 地理評, 51, 60 71.
森山昭雄・浅井道広 (1980)：矢作川河床堆積物と給 源岩石の造岩鉱物との粒度組成関係. 地理評, $\mathbf{5 3}$, $557 \sim 573$

森山昭雄・大橋保友 (1980) : 濃尾平野, 矢作川平野 における 2,000 年 B. P. 直前の旧海水準資料. 井 関弘太郎編：『完新世における旧海水準の認定と その年代に関する研究』1980年度文部省科学研究 費報告書, 45〜 57.

谷津栄寿 (1954)：平衡河川の縦断面形について(1), (2)，(3). 資源科学研究所彙報，33 号，15 24, 34 号, 14 21, 35号, $1 \sim 6$.

安田喜憲 (1971)：濃尾平野庄内川デルタにおける歴 史時代の地形変化. 東北地理, 23, 29 36.

林野庁 (1980) : 『矢作川流域管理計画調査 報 告 書』 林野庁, 369 ページ.

Ohomori, H. (1978) : Relief structure of the Japanese mountain and their stages in geomorphic developement. Bull. Dep. Geogr., Univ. of Tokyo, 10, 31 $\sim 85$.

Ohya, M. (1964) : Comparative study of the geomorphology and flooding in the plains of the Cho-Shui-Chi, Chao-Phraya, Irrawaddy and Ganges. Proceeding of the Dacca Symposium, $23 \sim 28$.

Oya, M. (1973) : Relationship between geomorphology of the alluvial plain and inundation. Asian Profile, 1-3. 479 538.

Rizvi, A. (1955) : Comparative physiography of the lower Ganges and lower Mississippi river. Doctorial Dissertation Series Publication, 12527. Michigan, $261 \mathrm{p}$.

Tricart, J, (1961) : Notice explicative de la cart géomorphologique du delta du SÉNÉGAL. Bureau de Recherches Géologiques et Minérales, $1 \sim 137$.

Volker, A. (1964) : The deltaic area of the Irrawaddy river in Burma. Proceedings of the Dacca Symposium, 373 379. 


\title{
COMPARATIVE STUDY ON THE FLUVIAL PLAIN OF THE SHONAI AND YAHAGI RIVERS, CENTRAL JAPAN, BASED ON THE GEOMORPHOLOGICAL LAND CLASSIFICATION
}

\author{
Shigeko HARUYAMA* and Masahiko OYA*
}

The writers studied on the geomorphology of fluvial plain distributed along the Shonai and Yahagi rivers running close each other. Geomorphological land classification maps of two fluvial plains revealed the distinct regional differences of fluvial morphology.

The Shonai river plain is composed of small scale natural levee, upper delta, lower delta and natural levee of the Kiso river, and the other hand, the Yahagi river plain is of fanlike natural levee, fan-like upper delta and fan-like lower delta. The above mentioned regional differences should be explained by the following data:

(a) Morphometric data of the Yahagi river basin, i.e., altimetric frequency, dispersion of altitude and average of relief energy, are larger than those of the Shonai. Easily weathered coarse grained granite is widely distributed in the Yahagi river basin but narrowly in the Shonai. Therefore, larger amount of detritus must be supplied to the river bed of the Yahagi as compared with the Shonai.

(b) Longitudinal gradient of the Shonai is gentle, only 5.3/1,000, and that of the Yahagi is slightly steeper, 9.2/1,000. Moreover, three gorges and three basins are distributed along the course of the Shonai; they are, from upper to lower reaches, the Mizunami basin, the Wago gorge, the Toki basin, the Toki gorge, the Tajimi basin and the Tamano gorge. Three knick points are found corresponding to the above three gorges. This means that the sediments supplied from the mountains to the plain through these three knick points is small in volume. On the other hand, there is only one small basin along the Yahagi river, i. e., the Toyota basin. The length of the Toyota gorge, between the basin and the plain, is short enough that a lot of detritus from the granitic basement area can be easily transported to the plain through the gorge.

(c) The thickness of fluvial layer on the marine deposits accumulated during the Jomon transgression $(6,000-4,000$ years B. P.) in the Shonai river plain is thinner than that in the Yahagi.

(d) The width of the flood plain is narrow in the upper part of the Shonai river plain because terraces are well developed on both sides of the plain. The flood plain in the middle part becomes wider due to the fact that this part of the plain is surrounded by natural levees formed by a distributary of the Kiso on the right side and terraces on the left. The flood plain in the lower part is widest, for there is no topographical limitation controlling the plain width. In respect to the Yahagi river plain, the width of the flood plain is nearly 
same from upper to lower cousres.

The change of the Shonai river course has rarely occurred in the upper and middle parts of the plain, but frequently in the lower part. Therefore, the flood types of the Shonai river plain are "Concentration type" in the upper part and "Overflow type" in the middle and lower parts. On the other hand, the change of the Yahagi river course has frequently occurred. The flood water causes short cuts at the meandering section in the upper part, and overflowing from the mainstream to the adjacent lowlands occurs in the lower part of the plain.

(Key words : geomorphological land classification, Shonai river, Yahagi river, natural levee, fan-like natural levee, delta, fan-like delta, overflow type, concentration type) 